\title{
Impact of Moisture Conservation Practices and Zinc Fertilization on Growth Parameter, Yield Attributes and Yield of Pearlmillet [Pennisetum glaucum (L.)] under Limited Moisture Conditions
}

\author{
Saroj Kumari Yadav ${ }^{\text {* }}$, B. L. Dudwal ${ }^{1}$, Hansa Choudhary ${ }^{1}, \operatorname{Sarita}^{2}$ and L. C. Yadav ${ }^{1}$ \\ ${ }^{1}$ Department of Agronomy, S.K.N College of agriculture, Jobner-303328 \\ ${ }^{2}$ Department of Agronomy College of Agriculture, Mandor, Jodhpur -342304
}

*Corresponding author

\begin{tabular}{|c|}
\hline Keywords \\
\hline $\begin{array}{l}\text { Pearlmillet, Pusa } \\
\text { hydrogel, Stover } \\
\text { mulch and zinc } \\
\text { fertilizer }\end{array}$ \\
\hline Article Info \\
\hline $\begin{array}{l}\text { Accepted: } \\
18 \text { January } 2020 \\
\text { Available Online: } \\
10 \text { February } 2020\end{array}$ \\
\hline
\end{tabular}

\section{A B S T R A C T}

a field experiment was conducted at Agronomy farm, S.K.N. College of Agriculture, Jobner (Rajasthan) during kharif, 2017 to find out the effect of moisture conservation practices and zinc fertilization on growth, yield and quality of pearlmillet. The experiment consisted of 20 treatment combinations of five moisture conservation practices i.e. control, dust mulch, pusa hydrogel, stover mulch and pusa hydrogel + stover mulch and four zinc fertilization levels i.e. control, $2 \mathrm{~kg} \mathrm{Zn} / \mathrm{ha}, 4 \mathrm{~kg} \mathrm{Zn} / \mathrm{ha}$ and $6 \mathrm{~kg}$ $\mathrm{Zn} / \mathrm{ha}$.Stover mulch recorded significantly higher plant height, dry matter accumulation, grain weight per ear heads, total number of tillers and effective tillers as compared to control, dust mulch and pusa hydrogel but remained at par with pusa hydrogel + stover mulch. Under zinc fertilization treatments application of $6 \mathrm{~kg} \mathrm{Zn} / \mathrm{ha}$ and $4 \mathrm{~kg} \mathrm{Zn/ha} \mathrm{being} \mathrm{at} \mathrm{par} \mathrm{with} \mathrm{each}$ other and proved significantly better over control, $2 \mathrm{~kg} \mathrm{Zn} / \mathrm{ha}$ in term of growth parameter, yield attributes and yield in pearlmillet. Final results revealed that application of stover mulch and $4 \mathrm{~kg} \mathrm{Zn} / \mathrm{ha}$ to pearlmillet were proved to be better.

\section{Introduction}

Pearlmillet [Pennisetum glaucum (L.) R. Br. emend Stuntz] commonly known as bajra, is an important drought hardy millet crop basically cultivated in the arid and semi-arid areas on light textured sandy soils. It is one of the major coarse grain crops and is considered to be a poor man's food. Pearlmillet grains are used for human consumption, its fodder as cattle feed and also used as feed for poultry. It is also grown and used for hay, pasture, silage, seed crops, food, building material and fuel. In India it is presently cultivated in area of 7.47 million hectare and producing 9.80 million tonnes with productivity of $1312 \mathrm{~kg}$ 
per hectare. In India major pearl millet producing state are Rajasthan (45\%), Uttar Pradesh (18\%) and Haryana (10\%) and Gujarat (9\%). In Rajasthan, Pearl millet is grown over an area of about 4.15 million hectare with the production of 4.16 million tones with average productivity $1001 \mathrm{~kg}$ per hectare (Anonymous, 2017). . In Rajasthan, Alwar, Sikar, Nagaur, Jaipur, Jodhpur and Jhunjhunu are major pearl millet producing districts with respect to area and production but productivity remains highest $(2095 \mathrm{~kg}$ $\mathrm{ha}^{-1}$ ) in Dholpur district.

Mulching is also one of the most important cultural technologies for conserving moisture in rainfed farming system. Mulch is reported to conserve soil moisture, protect soil from erosion, reduce soil temperature, minimize evaporation loss and enhance root growth. Dust mulching decrease evaporation on the assumption that dry soil acts as ablanket and also reduce the point of contact between the soil particles due to loosening attraction between them. Application of crop residue on soil surface as a mulch reduces the loss of water through evaporation and moderate the soil profile temperature (Ram et al., 2012)., There is 40 to 70 percent saving of water by the use of pusa hydrogel. Hydrogel reduces the leaching of herbicide, fertilizer and irrigation requirements for crops. It also promotes early dense flowering and tillering and delay the permanent wilting point (Mehr and Kourosh, 2008). At present, widespread and acute deficiency of zinc is another serious problem in arid and semi-arid region (Sahrawat et al., 2007).

Zn deficiency is occurring in both crops and human. Zinc deficiency reduces not only the grain yield, but also the nutritional quality of grain (Cakmak, 2008) and ultimately nutritional quality in human diet. Zinc plays avital role in synthesis of chlorophyll, protein and nucleic acid and helps in the utilization of nitrogen and phosphorous by plants as it acts an activator of dehydrogenase and proteinase enzymes, directly and indirectly in synthesis of carbohydrates and protein. Zinc is constituent of tryptophan which is precursor of auxin hormone.Chaube et al., (2007) and Badiyala and Chopra (2011) were reported that use of $\mathrm{Zn}$ increase the productivity as well as improve the fertility status of soil. Thus, keeping these facts in view, a research problem was undertaken to find out the effect of zinc fertilization under different moisture conservation practices on yield and economics of pearlmillet under rainfed conditions.Zinc is a divalent cation exhibiting important role in mankind health and functioning the various physiological and metabolic functions of plant (Alam et al., 2010). Thus, keeping these facts in view, a research problem was undertaken to find out the effect of zinc fertilization under different moisture conservation practices on growth attributes, yield attributes and yield of pearlmillet under rainfed conditions.

\section{Materials and Methods}

The present investigation entitled "Effect of moisture conservation practices and zinc fertilization on growth, yield and quality of pearlmillet (Pennisetum galaucum L.) Under rainfed condition" was carried out during kharif 2017 at Agronomy Farm of S.K.N. College of Agriculture, Jobner $\left(26^{0} 05^{\prime} \mathrm{N}\right.$ latitude and $75^{\circ} 28^{\prime} \mathrm{E}$ longitude and at an altitude of 427 metres above mean sea level). The region falls in Agro-climatic zone III-a (Semi-Arid Eastern Plain) of Rajasthan. The climate of this region is a typically semi-arid, characterized by extremes of temperature during both summers and winters. The average annual rainfall of this tract varies from $300 \mathrm{~mm}$ to $400 \mathrm{~mm}$ and is mostly received during the month of July to September. During summer, temperature may go as high as $48^{\circ} \mathrm{C}$ while in winter, it may fall 
as low as $-1.5{ }^{0} \mathrm{C}$. the relative humidity fluctuates between 43 to 87 per cent. The experimental soil was loamy sand in texture with high infiltration rate $(22.4 \mathrm{~cm} / \mathrm{hr})$ and saturated hydraulic conductivity $10.20 \mathrm{~cm} / \mathrm{h}$. The soil was low in organic carbon $(0.24 \%)$, low available nitrogen (125.7 kg N/ha) and $\mathrm{Zn}(0.4 \mathrm{mg} / \mathrm{kg}$ of soil $)$, medium in available phosphorus (16.12 $\left.\mathrm{kg} \quad \mathrm{P}_{2} \mathrm{O}_{5} / \mathrm{ha}\right)$ and in available potassium (151.24 $\left.\mathrm{kg} \mathrm{K}_{2} \mathrm{O} / \mathrm{ha}\right)$. The soil was non saline with a $\mathrm{pH}$ value of 8.2.The experiment was laid out in randomized block design (RBD) comprised of five treatments of moisture conservation practices (control, dust mulch, pusa hydrogel, stover mulchand pusa hydrogel + stover mulch) and four treatments of zinc fertilization (control, $2.0 \mathrm{~kg} \mathrm{Zn} / \mathrm{ha}$ and $4.0 \mathrm{~kg} \mathrm{Zn} / \mathrm{ha}$ and $6.0 \mathrm{~kg} \mathrm{Zn/ha)} \mathrm{in}$ pearlmilletwith three replications.

The pearlmillet variety 'RHB -173' was taken for experiment and planted at $45 \mathrm{~cm} \mathrm{x} 10 \mathrm{~cm}$ spacing. Pusa hydrogel was applied inrespective plots as band andZinc fertilization treatments were applied as per treatment through zinc sulphate ( $\mathrm{ZnSO} 4.7 \mathrm{H} 2 \mathrm{O})$ containing $21 \%$ zinc and $10 \%$ $\mathrm{S}$ at the time of sowing as basal dose. The crop was grown with recommended package of practices. The weight of the thoroughly sun dried harvested produce from net area of each plot was recorded separately before threshing and expressed as biological yield in $\mathrm{kg} / \mathrm{ha}$. After proper drying harvested produce were threshed separately.

Grain yield from each net plot was recorded and computed as grain yield $\mathrm{kg} / \mathrm{ha}$. The stover yield for each plot was worked out by subtracting grain yield from total biomass of each net plot andstover yield was expressed in $\mathrm{kg} / \mathrm{ha}$. Economics of different treatment was worked out by taking into account the cost of inputs and income obtained from output based on the prevailing market price.

\section{Results and Discussion}

\section{Effect of moisture conservation practices on pearlmillet}

\section{Effect on growth attributes}

The moisture conservation practices did not significant influenced on plant stand at 20 DAS and harvest. Growth parameters viz., plant height, dry matter accumulation, and total number of tillerswas significantly influenced by moisture management practices. Significantly taller plants (149.60 and $173.74 \mathrm{~cm}$ at 60 DAS and at harvest, respectively) were observed under the treatment stover mulch which was at par with pusa hydrogel + stover mulch. The data presented in Table-1 revealed that dry matter accumulation of pearlmillet per metre row length recorded at 30, $60 \mathrm{DAS}$ and at harvest was found significantly higher in stover mulch which was at par with pusa hydrogel + stover mulch. Among the moisture conservation practices on average significantly higher number of tillers (4.77) per plant recorded at harvest under treatment stover mulch. Rapid decomposition of organic residue helped in greater availability of nutrients, which led to increase in growth and yield attributes and finally the grain yield. Similar findings were also reported by Kumar and Gautam (2004) and Parihar et al., (2012).

\section{Effect on yield and yields attributes}

The different soil moisture conservation practices significantly influenced yield attributing and yields of pearlmillet. The result revealed that treatment stover mulch recorded significantly the highest values of effective tillers per plant, number of grains per ear, length of ear, test weight, than control, dust mulch and pusa hydrogel but remained at par with pusa hydrogel + stover mulch. 
Table.1 Effect of moisture conservation practices and zinc fertilization on growth parameter of pearlmillet

\begin{tabular}{|c|c|c|c|c|c|c|c|c|}
\hline \multirow[t]{2}{*}{ Treatments } & \multicolumn{2}{|c|}{$\begin{array}{l}\text { Plant stand/ m row } \\
\text { length }\end{array}$} & \multicolumn{3}{|c|}{ Plant height (cm) } & \multicolumn{3}{|c|}{$\begin{array}{l}\text { Dry matter accumulation } \\
(\mathrm{g} / \mathrm{mrl})\end{array}$} \\
\hline & $20 \mathrm{DAS}$ & At harvest & $30 \mathrm{DAS}$ & $60 \mathrm{DAS}$ & At harvest & 30 DAS & $60 \mathrm{DAS}$ & At harvest \\
\hline \multicolumn{9}{|l|}{$\begin{array}{l}\text { Moisture conservation } \\
\text { practices }\end{array}$} \\
\hline Control & 7.19 & 7.05 & 29.65 & 114.44 & 132.47 & 15.06 & 99.48 & 135.52 \\
\hline Dust mulch & 7.28 & 7.12 & 29.95 & 126.50 & 146.23 & 17.02 & 109.29 & 147.51 \\
\hline Pusa hydrogel & 7.31 & 7.17 & 30.20 & 138.50 & 160.69 & 19.49 & 119.82 & 160.09 \\
\hline Stover mulch & 7.33 & 7.19 & 31.40 & 149.60 & 173.74 & 21.50 & 129.97 & 173.05 \\
\hline Pusa hydrogel + stover mulch & 7.38 & 7.25 & 31.99 & 154.30 & 179.39 & 22.41 & 136.81 & 181.29 \\
\hline SEM \pm & 0.18 & 0.18 & 0.99 & 3.61 & 4.22 & 0.52 & 3.19 & 4.24 \\
\hline $\mathrm{CD}(\overline{\mathbf{P}}=\mathbf{0 . 0 5})$ & NS & NS & NS & 10.32 & 12.08 & 1.49 & 9.14 & 12.13 \\
\hline \multicolumn{9}{|l|}{ Zinc level (kg Zn/ha) } \\
\hline 0 & 7.21 & 7.01 & 29.49 & 119.75 & 136.54 & 15.54 & 102.26 & 139.06 \\
\hline 2 & 7.26 & 7.17 & 30.47 & 132.09 & 149.97 & 18.33 & 115.17 & 153.44 \\
\hline 4 & 7.34 & 7.21 & 31.06 & 144.85 & 170.64 & 20.78 & 126.39 & 169.28 \\
\hline 6 & 7.37 & 7.23 & 31.55 & 149.98 & 176.87 & 21.73 & 132.48 & 176.19 \\
\hline SEM \pm & 0.16 & 0.16 & 0.89 & 3.23 & 3.77 & 0.47 & 2.85 & 3.79 \\
\hline $\mathrm{CD}(\overline{\mathbf{P}}=\mathbf{0 . 0 5})$ & NS & NS & NS & 9.23 & 10.80 & 1.34 & 8.17 & 10.85 \\
\hline
\end{tabular}


Table.2 Effect of moisture conservation practices and zinc fertilization on yield attributes and yield of pearlmillet

\begin{tabular}{|c|c|c|c|c|c|c|}
\hline Treatments & $\begin{array}{c}\text { Total } \\
\text { Tillers/plant }\end{array}$ & $\begin{array}{c}\text { Effective } \\
\text { tillers/plant }\end{array}$ & $\begin{array}{c}\text { Number of } \\
\text { grain/ear }\end{array}$ & $\begin{array}{c}\text { Ear length } \\
(\mathrm{cm})\end{array}$ & $\begin{array}{c}\text { Test weight } \\
\text { (g) }\end{array}$ & $\begin{array}{c}\text { Grain yield } \\
\text { (kg/ha) }\end{array}$ \\
\hline \multicolumn{7}{|l|}{$\begin{array}{l}\text { Moisture conservation } \\
\text { practices }\end{array}$} \\
\hline Control & 3.56 & 2.08 & 724.53 & 18.71 & 5.84 & 1905 \\
\hline Dust mulch & 3.97 & 2.35 & 795.30 & 20.67 & 6.40 & 2112 \\
\hline Pusa hydrogel & 4.37 & 2.61 & 875.40 & 22.87 & 6.95 & 2306 \\
\hline Stover mulch & 4.77 & 2.89 & 978.45 & 24.79 & 7.49 & 2511 \\
\hline $\begin{array}{l}\text { Pusa hydrogel }+ \text { stover } \\
\text { mulch }\end{array}$ & 4.98 & 3.06 & 1040.20 & 25.81 & 7.91 & 2613 \\
\hline SEM \pm & 0.12 & 0.07 & 24.00 & 0.56 & 0.18 & 60 \\
\hline $\mathrm{CD}(\mathrm{P}=0.05)$ & 0.34 & 0.20 & 68.71 & 1.60 & 0.53 & 173 \\
\hline \multicolumn{7}{|l|}{ Zinc level (kg Zn/ha) } \\
\hline $\mathbf{0}$ & 3.54 & 2.20 & 764.63 & 19.66 & 6.11 & 1954 \\
\hline 2 & 4.19 & 2.45 & 832.49 & 21.89 & 6.66 & 2246 \\
\hline 4 & 4.69 & 2.80 & 942.52 & 23.97 & 7.29 & 2470 \\
\hline 6 & 4.90 & 2.94 & 991.46 & 24.76 & 7.61 & 2486 \\
\hline SEM \pm & 0.10 & 0.06 & 21.47 & 0.50 & 0.16 & 54 \\
\hline $\mathrm{CD}(\mathrm{P}=\mathbf{0 . 0 5})$ & 0.30 & 0.18 & 61.46 & 1.43 & 0.47 & 155 \\
\hline
\end{tabular}


Yield attributes and yield could be attributed to improvement in growth attributes through availability of more moisture and nutrients, which in turn favourably influenced number of physiological processes like transpiration, photosynthesis and build-up of food material. The increase in grain yield with increase in yield attributes may also be supported by significant and positive correlation between grain yield and yield attributes. These results are in conformity with findings of Sujatha et al., (2013) Menaka et al., (2008), Jalota et al., (2007), and Tetarwal and Rana (2006).

\section{Effect of zinc fertilization in pearlmillet}

\section{Effect on growth attributes}

Zinc fertilization with 4 and $6 \mathrm{~kg} \mathrm{Zn} / \mathrm{ha}$ being at par with each other, proved significantly better over control and $2 \mathrm{~kg} \mathrm{Zn} / \mathrm{ha}$ in terms of growth parameters (plant height, dry matter accumulation and total number of tillers), at most of the growth stages of pearlmillet. The favourable influence of applied zinc on different growth parameters of pearlmillet ascribed to its involvement in various metabolic activities, controlling auxin levels and nucleic acids. The improvement in growth parameters with zinc fertilization were also reported by Jakhar et al., (2006), Badiyala and Chopra (2011), Gupta and Sahu (2012) and Singh and Bhati (2013).

\section{Effect on yield attributes}

The considerable improvement in yield attributes viz., number of effective tillers, number of grains per ear, weight of ear, length of ear and test weight were observed due to zinc fertilization. Increasing levels of zinc fertilization up to $4.0 \mathrm{~kg} \mathrm{Zn} / \mathrm{ha}$ significantly increased the number of effective tillers, number of grain, and 1,000 grain weight of pearlmillet as compared to control and $2 \mathrm{~kg} \mathrm{Zn} / \mathrm{ha}$ but it was at par with 6 $\mathrm{kg} \mathrm{Zn/ha.} \mathrm{Zinc} \mathrm{plays} \mathrm{an} \mathrm{important} \mathrm{role} \mathrm{in}$ nitrogen metabolism and formation of chlorophyll and carbohydrate, which leads to maintain photosynthetic activity for longer period and finally results in increasing the yield attributes of the crop. Similar findings were also reported by Mehta et al., (2008), Ram Pratap et al., (2008) and Jyothi et al., (2013). Zinc plays a pivotal role in regulating the auxin concentration in plant and nitrogen metabolism and might have improved these growth attributes. In dry land areas $\mathrm{Zn}$ application increases root absorption of minerals; these results are in close conformity with those of Dashadi et al., (2013) and Kumawat et al., (2015).

Based on the results of this experiment, it may be concluded that in moisture conservation practices stover mulch was found significantly most suitable treatment for obtaining higher growth and yield attributes but it was at par with pusa hydrogel + stover mulch and in zinc fertilization $4 \mathrm{~kg} \mathrm{Zn/ha} \mathrm{was}$ found significantly superior than control and $2 \mathrm{~kg} \mathrm{Zn} / \mathrm{ha}$ but it was at par with $6 \mathrm{~kg} \mathrm{Zn} / \mathrm{ha}$. However, these results are only indicative and require further experimentation to arrive at more consistent and final conclusion.

\section{Acknowledgement}

We sincerely thank to head and my advisor, Division of Agronomy, S.K.N. college of Agriculture, Jobner for providing field staff, facilities and assistance in conducting this research.

\section{References}

Alam, M.N., Abedin, M.J., Azad, M.A.K. 2010.Effect of micronutrients on growth and yield of onion under calcareous soil environment. International Research Journal of Plant Science 1(3):56-61.

Anonymous. 2017. Agricultural Statistics at a 
Glance 2016. Department of Agriculture, Cooperation and Farmers Welfare, Directorate of Economics and Statistics.

Badiyala, D. and Chopra, P. 2011. Effect of zinc and farm yard manure on productivity and nutrient availability in maize (Zea mays) - linseed (Linum usitatissium) cropping sequence. Indian Journal of Agronomy 56 (2): 88-91.

Cakmak, I. 2002. Role of zinc in protecting plant cell from reactive oxygen species. New Phytologist 146: 464-465.

Chaube, A.K., Ruhella, R., Chakraborty, R., Gangwar, M.S., Srivastva, P.C. and Singh, S.K. 2007.Management of zinc fertilizer and pearlmillet (Pennisetum glaucum) - wheat (Triticum asetivam) cropping system in a typicustipsamment. Journal of the Indian society of soil science 55(2): 196-202.

Dashadi, M., Hossein, A., Radjabi, R. and Babainejad, T. 2013.Investigation of effect different rates Phosphorus and Zinc fertilizers on two cultivars Lentil Gachsaran and Flip92-12L) in irrigation complement condition. International Journal of Agriculture Crop Science5(1):1-5.

Gupta, S.C. and Sahu, S. 2012. Response of chickpea to micronutrients and biofertilizers in vertisol. Legume Research, 35(3): 248-251.

Jakhar, S.R., Singh, M. and Balai, C.M. 2006. Effect of farm yard manure, phosphorus and zinc levels on growth, yield, quality and economics of pearlmillet (Pennisetum glaucum). Indian Journal of Agricultural Sciences 76(1): 58-61.

Jalota, SK., RomeshKhera, Arora VK, Beri V. 2007.Benefits of straw mulching in crop production a review. Journal of Research, Punjab Agricultural University 44(2):104-107.

Jyothi, C.N., Ravichandra, K. and Babu, K.S.
2013.Effect of foliar supplementation of nitrogen and zinc on soybean (Glycine $\max$ L.) yield, quality and nutrient uptake. Indian Journal of Dryland Agricultural Research and Development 28(2): 46-48.

Kumar, N. and Gautam, R.C. 2004.Effect of moisture conservation and nutrient management practices on growth and yield of pearlmillet (Pennisetum glaucum) under rainfed condition. Indian Journal of Agronomy 49(3): 182185.

Kumawat, S.K., Yadav, B.L., Kumawat, S.R. 2015 Response of fennel (Foeniculum vulgare Mill.) to phosphorus and zinc fertilization in a loamy sand soil. Journal of Spices and Aromatic Crops 24(1):23-27.

Mehr, M.J.Z. and Kourosh, K. 2008. Superabsorbent Polymer Materials: A Review. Iranian Polymer Journal17 (6): 451-477.

Menaka C, Vanangamudi K, Renganayaki PR, Lakshmi S. Seed hardening and pelleting to increase the productivity of pearl millet under rain fed condition. Research on crops. 2008; 9(3):704-706.

Parihar, C.M., Rana, K.S., Jat, M.L., Jat, S.L., Parihar, M.D., Kantwa, S.R., Singh, D.K. and Sharma, S. 2012. Carbon footprint and economic sustainability of pearlmillet-mustard system under different tillage and nutrient management practices in moisture stress conditions. African Journal of Microbiology Research 6(23): 50525061.

Pratap, R., Sharma,O.P. and Yadav, G.L. 2008. Effect of integrated nutrient management under varying levels of zinc on pearlmillet (Pennisetum glaucum) yield. Annals of Arid zone 47(2): 197-199.

Ram, H., Singh, Y., Saini, K.S., Kler, D.S., Timsina, J. and Humphreya, E.J. 2012. 
Agronomic and economic evaluation of permanent raised beds, no tillage, sand and straw mulching for an irrigated maize (Zea mays) -wheat (Triticum aestivam) system in North-West India. Experimental Agriculture 48(1): 21-38.

Sahrawat, K.L., Wani, S.P., Rego, T.J., Pardhasoradhi, $G$ and Murthy, K.V.S. 2007. Widespread deficiencies of sulphur, boron and zinc in dryland soils of the Indian semi-arid tropics. Current Science, 93(10): 1428-1432.

Singh, A.K. and Bhati, B.P. 2013. Effect of foliar application of zinc on growth and seed yield of late-sown lentil (Lens culinaris). Indian Journal of Agricultural Sciences 83(6): 622-626.

Sujatha, K., Sivasubramaniam, K., Padma, J. and Selvarani, K. 2013. Seed hardening. International Journal of Agricultural Science 9(1): 392-412.

Tetarwal, J.P. and Rana, K.S. 2006.Impact of cropping system, fertility level and moisture conservation practices on productivity, nutrient uptake, water use and profitability of pearlmillet (Pennisetum glaucum) under rainfed condition. Indian Journal of Agronomy 51(4): 263-266.

\section{How to cite this article:}

Saroj Kumari Yadav, B. L. Dudwal, Hansa Choudhary, Sarita and Yadav, L. C. 2020. Impact of Moisture Conservation Practices and Zinc Fertilization on Growth Parameter, Yield Attributes and Yield of Pearlmillet [Pennisetum glaucum (L.)] under Limited Moisture Conditions. Int.J.Curr.Microbiol.App.Sci. 9(02): 2565-2572. doi: https://doi.org/10.20546/ijcmas.2020.902.292 